\title{
Special issue editorial: “Organizing for pricing excellence”
}

\author{
Stephan M. Liozu ${ }^{1}$ - Andreas Hinterhuber ${ }^{2}$
}

Published online: 6 March 2021

(c) The Author(s), under exclusive licence to Springer Nature Limited 2021

\section{Introduction}

Pricing is a transformation innovation (Liozu 2015b). To reach the pricing power zone (Hinterhuber and Liozu 2012), firms and their pricing leaders need to focus on both the technical and the social sides of pricing (Liozu 2016). In fact, the full impact of pricing can only be reached when firms focus on both pricing strategy and pricing execution. And successful pricing execution requires processes, capabilities, change management, and the support of top leadership (Hinterhuber and Liozu 2019).

Despite the publication of an increasing number of papers related to the organizational and social dimensions of pricing, much of the attention to pricing by consultants, practitioners, and scholars continues to focus on its technical, analytical side (Hinterhuber and Liozu 2015). Most pricing elective courses proposed in MBA program focus solely on the quantitative and analytical while seriously neglecting aspects of organizational design for pricing, cultural implications of pricing transformations, and soft-skill requirements for transforming pricing mindsets (Liozu 2015a).

Organizing for effective pricing has been a limited but central research topic since the inception of research on pricing: in Pricing in Big Business (Kaplan et al. 1958), Kaplan dedicates an entire chapter to pricing organization. What began as descriptive research is now a growing, albeit small, body of increasingly prescriptive research on price delegation (Frenzen et al. 2010; Stephenson et al. 1979), the interdepartmental centralization of pricing (Homburg et al. 2012), the organizational configuration of price management (Burkert et al. 2017), the role of CEOs in organizing pricing

Stephan M. Liozu

sliozu@case.edu

Andreas Hinterhuber

andreas.hinterhuber@unive.it

Case Western Reserve University, Cleveland, USA

2 Department of Management, Ca' Foscari University of Venice, Veneto, Italy
(Liozu and Hinterhuber 2013), pricing capabilities (Töytäri and Rajala 2015), and other related issues. More recently, scholars have paid more attention to the individual factors influencing team or organization pricing decisions (Hinterhuber and Liozu 2017). The focus on micro-foundations of pricing has revealed interesting findings related to biases and preferences in individual team members and how these influence pricing orientation and organization (Kienzler 2018).

Nevertheless, compared with other salient aspects of marketing, our understanding of what constitutes excellence in organizing the pricing function is arguably shallow. To cite a few examples, we know little about how to configure the pricing function to increase overall firm performance. We know little about the origins and evolution of pricing capabilities and how dynamic pricing capabilities enable dynamic strategies. We lack understanding of pricing metrics and of psychological or behavioral traits of effective pricing managers. Finally, pricing continues to be ignored by $\mathrm{C}$-suite executives despite strong evidence of direct impact on the bottom line. From an academic perspective, pricing continues to be neglected.

\section{Motivation for the special issue}

Over the past ten years, we have devoted our attention to researching the field of pricing from an organization, behavioral, and psychological perspective. From special issues to books to research papers, we have strived to fill the gap and help pricing practitioners be more successful by embracing these unique dimensions of the pricing discipline. The motivation for this special issue continues this effort. We wanted to propose a vehicle for scholars and practitioners to share their experiences and research findings to advance the pricing field. Our resolve to make the pricing discipline a more complete one is unchanged. We continue to believe that there is a great need for additional empirical inquiries focused on pricing's organizational, social, and behavioral dimensions. 


\section{Content of the special issue}

After distributing the call for papers through various channels, we generated tremendous interest in the topic for our special issue. However, the COVID-19 pandemic challenged our ability to secure commitments from potential contributors. It also complicated the review process, as scholars were busy redesigning their curriculum for an all-virtual environment. Our efforts and the double-blinded review process yielded four papers for this special issue. Three of these papers are empirical studies focused on the specific topic of organizing for pricing. The fourth is a practice paper focused on the management of value and pricing in organizations.

The first paper, "The adoption of pricing from an organizational perspective and its impact on relative firm performance," by Stephan Liozu, investigates the influence of four organizational factors on the adoption of pricing and the impact of increased pricing adoption to relative firm performance. Based on responses from 540 pricing practitioners, the results highlight the positive influence of organizational alignment, cross-functional collaboration, and top championing support on the adoption of pricing. They also reveal that too much formalization in the pricing process negatively influences adoption. Finally, the paper concludes that the greater the adoption of pricing, the greater the relative firm performance.

The second paper, "Value first then price: the new paradigm of B2B buying and selling," by Andreas Hinterhuber, Todd Snelgrove, and Bo-Inge Stensson, explores ways to remedy the adversarial approach between buyers and sellers in order to improve profitability. The authors present a set of principles that enable companies to put joint value creation at the center of their relationships with suppliers and customers.

The third paper, "Factors that contribute to managers becoming engaged in unintentional price war," by Richard Cardot, Dick Boland, and Stephan Liozu, focuses on a qualitative inquiry to better understand price-war behaviors in firms. This paper highlights the factors that lead well-educated pricing managers into price wars despite their desire to avoid them. This qualitative inquiry involved semi-structured interviews with 25 pricing managers across five industries. The findings confirm that pricing managers have a strong desire to avoid price wars and that pricing managers frequently blame competitors for aggressive pricing action. The paper also identifies several common characteristics among the study participants.

The fourth and final paper examines the presence and impact of complex alternative organizational configurations of pricing on firm performance. The dataset is from a survey of company owners and company CEOs, of which a subsample was used previously and analyzed with multiple regression analysis. Stephan Liozu, Sven Feurer, Andreas Hinterhuber, and Arch Woodside propose analysis of an enlarged dataset that includes new data, using fuzzy-set qualitative comparative analysis (fsQCA). The findings support the perspective that multiple price-policy paths are identifiable for indicating high performance for different firm operational contexts. By applying the perspective of complex interdependencies of specific pricing activities and specific organizational configurations related to pricing, this study offers a nuanced contribution to marketing theory. To practicing managers, it offers guidance for adopting specific configurations of pricing policies in specific contexts for achieving high firm performance as well as for which configurations indicate negative firmperformance outcomes.

\section{Concluding thoughts}

This is clearly insufficient to make a dent in the vast gap we highlighted in the introduction of this editorial. But these four papers contribute to our argument that more attention needs to be given to the nontechnical dimension of pricing. We offer four papers with different methodologies and different sets of hypotheses related to the organization of the pricing discipline. We encourage pricing, marketing, management, and organizational behavior scholars to continue to investigate the pricing discipline through different lenses. As more and more firms begin pricing journeys, we hope, through the dissemination of empirical and evidence-based research, to guide them in their quest for greater pricing excellence.

\section{References}

Burkert, M., B.S. Ivens, S. Henneberg, and P. Schradi. 2017. Organizing for value appropriation: Configurations and performance outcomes of price management. Industrial Marketing Management 61: 194-209.

Frenzen, H., A.K. Hansen, M. Krafft, M.K. Mantrala, and S. Schmidt. 2010. Delegation of pricing authority to the sales force: An agency-theoretic perspective of its determinants and impact on performance. International Journal of Research in Marketing 27 (1): $58-68$.

Hinterhuber, A., and S.M. Liozu. 2012. Is it time to rethink your pricing strategy? MIT Sloan Management Review 53 (4): 69-77.

Hinterhuber, A., and S.M. Liozu. 2015. Editorial: Behavioral and psychological aspects of B2B pricing. Industrial Marketing Management 47: 4-5.

Hinterhuber, A., and S.M. Liozu. 2017. The micro-foundations of pricing. Journal of Business Research 76 (July): 159-162.

Hinterhuber, A., and S.M. Liozu. 2019. Pricing strategy implementation: Translating pricing strategy into results. Abingdon: Routledge. 
Homburg, C., O. Jensen, and A. Hahn. 2012. How to organize pricing? Vertical delegation and horizontal dispersion of pricing authority. Journal of Marketing 76 (5): 49-69.

Kaplan, A., J. Dirlam, and R. Lanzillotti. 1958. Pricing in big business: A case approach. Washington, DC: Brookings Institution.

Kienzler, M. 2018. Value-based pricing and cognitive biases: An overview for business markets. Industrial Marketing Management 68: 86-94.

Liozu, S.M. 2015a. Pricing and human capital: A guide to developing a pricing career, managing pricing teams, and developing pricing skills. Abingdon: Routledge.

Liozu, S.M. 2015b. The pricing journey: The organizational transformation toward pricing excellence. Stanford, CA: Stanford University Press.

Liozu, S.M. 2016. Value mindset. Sewickley, PA: VIA Publishing.

Liozu, S.M., and A. Hinterhuber. 2013. CEO championing of pricing, pricing capabilities and firm performance in industrial firms. Industrial Marketing Management 42 (4): 633-643.

Stephenson, P.R., W.L. Cron, and G.L. Frazier. 1979. Delegating pricing authority to the sales force: The effects on sales and profit performance. The Journal of Marketing 43 (2): 21-28.
Töytäri, P., and R. Rajala. 2015. Value-based selling: An organizational capability perspective. Industrial Marketing Management 45: 101-112.

Publisher's Note Springer Nature remains neutral with regard to jurisdictional claims in published maps and institutional affiliations.

Stephan M. Liozu is an Adjunct Professor and Research Fellow at the Weatherhead School Management at Case Western Reserve University in Cleveland, OH. He is also the Chief Value Officer of the Thales Group. He can be contacted at sliozu@case.edu

Andreas Hinterhuber is Associate Professor of Marketing at Università Ca' Foscari Venezia. His research interests focus on strategic pricing, customer value management, digital strategies, and value quantification. 